brazilianpoliticalsciencereview

ART I CLE

\title{
Reversing Polarities: Anarchical (Failed) States versus International Progress*
}

\author{
Marta Fernandez Moreno \\ Pontifícia Universidade Católica do Rio de Janeiro, Brazil
}

\begin{abstract}
The article explores how the literature on 'failed states' (re)produces the modern state as a regulatory ideal, obscuring its contingent character and its violent foundation. So, discursive practices, based on an Eurocentric account, construct the 'failed state' as deviant. The resultant hierarchy of states, in turn, creates favorable conditions for interventionist practices, whose agents are depicted as members of a 'progressive' and 'benevolent' 'international community'. As state failure is interpreted as exclusively domestic process, a well-demarcated boundary between the domestic level of 'anarchy' and the international realm of 'order' and 'progress' results. This article shows that the traditional image of an anarchical system versus an ordered and progressive state is turned on its head when viewed from the perspective of 'failed states'. In the latter, domestic anarchy is contrary to a modernizing international realm. By labelling the 'other' as 'traditional', 'failed', and 'backward' in distinction to a 'modern', 'successful' and 'progressive' international, the dominant discourse conditions us to conceive of these realms as homogeneous in themselves and radically different from each other, rather than as liminal areas with numerous ambiguities and overlaps.
\end{abstract}

Keywords: Failed states; international progress; intervention; pre-modernity; temporalisation of difference. 
omalia, Rwanda, Liberia, Haiti. Such countries have usually been conceptualized under a single and simplifying category-'failed states'-instead of being considered in their contingencies and singularities. This predetermination of our political imagination is articulated by the vast literature on 'failed states' produced by academics, journalists and politicians since the end of the Cold War. The main goal of most of this literature is to accumulate abundant knowledge about such states in order to develop a rigorous definition of them that might allow the provision of a series of practical recommendations to solve their alleged condition of 'failure' or, in more contemporary terms, "fragility".

Contrarily, this article analyses the category of 'failed states' as a discursive practice rather than as an explanation of some objective reality. Therefore, it understands that the discourse on 'failed states' is not a description of an innocent world 'out there', since it participates in the production of this world (of sovereign states).

The first section clarifies the discourse analysis employed in the article. By analysing the discourse on 'failed states', the second section attempts to answer the following question: how does the discourse on state failure participate in the (re)production of the state as norm? The third section explores how 'failed states' are usually thought of as a temporal category. The fourth section argues that the 'failed state' discourse creates conditions for the possibility of interventionist practices-of state reconstruction-by supposedly 'benevolent' and 'temporally advanced' actors. The fifth section suggests that such discourse and the interventions it authorises participate in the production of the 'international' as a modern/progressive realm-thus contradicting its traditional conception as an anarchic realm of recurring conflicts. Finally, the sixth section explores how the internalization of the causes of conflicts in failed states works as a discursive practice, constructing these states as disconnected from a 'tolerant' and 'benevolent' international community. As I will try to indicate, failed states are seen as primarily responsible for the conflicts that take place within their borders.

\section{A Discourse Analysis of "Failed States"}

The analytical strategy adopted here, informed by post-structuralism, takes advantage of discourse analysis to understand the "reality". According to 
Foucault, "reality" - subject, object and their relationships - only becomes intelligible through discourse, which means that "reality" cannot be understood in the absence of interpretation (see DOTY, 1993; MALMVIG, 2006). As stated by Lene Hansen (2006), language is a political act since it is always subjective and questionable (HANSEN, 2006).

For Foucault (2004), the "world" is produced by discursive practices. In this sense, the "world" does not have an ontological foundation but is, rather, a product of the power that operates through language. According to Foucault (2004), there is no possibility of exercising power without a certain economy of discourses of truth; that is, power relations cannot be established without a certain production, accumulation and circulations of discourses of truth (FOUCAULT, 2004).

Thus, the "world" no longer can be seen as an empirical referent in which knowledge and truth shall meet and to which they shall refer (MALMVIG, 2006). Language is not conceived, as assumed by positivism, as a transparent instrument which serves as a conduit between thoughts/concepts and things (SHAPIRO, 1989). To the extent that discourses do not refer to an essence or to a stable referent, but only to other discursive practices, any analysis of "reality" can claim the stamp of authenticity (BROWN, 1994).

Since the discourse does not derive from an intention of a conscious actor, it does not function, as claimed by realist theorists, as merely a guise to advance interests. Differently, for Foucault (2004), the subject itself is seen as a product of discourse and, therefore, that subject is not previous to the discourse. In the words of Foucault (2004): "The individual (...) is not the vis-à-vis power; it is, I believe, one of its prime effects. The individual is an effect of power, and the same time, or precisely to the extent to which it is that effect, it is the element of its articulation" (FOUCAULT, 2004, pp. 183,184). As Malmvig (2006) remarks, discursive articulations are not seen as rhetorical superficial phenomena, behind which we can find a real cause or an extra-discursive foundation, like interest or power. As shown by Doty, the central question for post-structuralist thinkers is not worded as a "why question", but rather formulated in terms of "how-possible". According to Doty (1993), questions formulated in such way have the power to analyse not only how social identities are constructed but also how certain policies 
have become possible. For Doty (1993), such questions illuminate an aspect of power neglected by the "why questions": namely, the way in which power operates to construct particular modes of subjectivity and interpretative dispositions. This kind of power cannot be understood as one that pre-existing social actors possess and use. Rather, it produces a variety of meanings and imaginable behaviours and, as such, it is in Foucault's terms "productive". The power inherent in language is productive in that it produces the "world" and has practical effects, enabling and legitimizing certain actions while precluding and discrediting others (DOTY, 1993).

By describing certain states (such as failed or fragile states) as imperfect representations of the modern state, the literature is not adopting a neutral effort to better understand these states but, differently, is producing what should be governed and disciplined. The identity assigned to such states and their people, by most of the mainstream literature of International Relations as well as by media and other discourses, produces them as natural candidates for interventions undertaken in the name of human progress.

The discursive analysis proposed here has clear political significance since, by unveiling the productivity of the discourse, the article aims to denaturalize the current forms of knowledge and, in doing so, to expose the practices made possible by such forms of knowledge (MILLEKEN, 1999) to critical interrogation.

\section{The successful state and its shadow: the discourse on state failure}

The literature on state reconstruction is closely associated with the literature on 'failed states', since the latter are the targets of peace operations that aim to establish a legitimate and functional sovereign state. According to Christopher Bickerton (2007), "the idea that states can fail is obviously the precursor to the idea that states need to be rebuilt. Only after the idea that states could fail had been established was it possible for internationalized state-building to be mooted to an acceptable solution" (BICKERTON, 2007, p. 102).

Underlying each definition of a 'failed state' are definitions of what constitutes a 'successful state' (HILL, 2005). As a regulatory ideal, the 'successful state' is invested with qualities that are missing in the so-called 'failed state'. Therefore, the norm regulating the United Nations (UN) operations of state 
reconstruction can be inferred from the study of what the dominant discourse considers the exception-the 'failed state'. This central role played by the exception has been remarked by Carl Schmitt (1985), according to whom "the exception is more interesting than the rule. The rule proves nothing; the exception proves everything: it confirms not only the rule but also its existence, which derives only from the exception" (SCHMITT, 1985, p.15).

Post-structural thinkers understand the supposedly 'neutral' and 'factual' descriptions of failed states as exercises of power, since they work as productive practices of identity construction (see DOTY, 1996). By labelling states 'failed', one names what they are not rather than what they are, thus precluding the possibility of taking states as objects of study per se. Thus, instead of thinking of alternative paths for these societies as legitimate objects of analysis, most analysts assume their development to be, beforehand, an abnormality (see HAGMANN, 2005).

In this sense, the state acts as the norm in relation to which other forms of political organization are judged, denied, punished or inferiorized. The 'other', vis$\grave{a}$-vis the 'successful modern state', is not only described as different, but their difference is demoted, presented as negative. 'Failed states' are therefore constructed as anomalies, which supports their characterization as ill and decrepit.

Gerald Helman and Steven Ratner (1992), for instance, equate state failure to a serious physical and mental illness. Terrence Lyons and Ahmed Samatar (1995) establish a parallel between the process of state failure in Somalia and a long and complex degenerative disease. According to these authors, "state collapse is not a short-term phenomenon, but a cumulative, incremental process similar to a degenerative disease. Governments lose their ability to exercise legitimate authority unevenly over territory" (LYONS and SAMATAR, 1995, p. 01). Robert Jackson (2000), in turn, requests foreigners to be aware of the risks 'failed states' pose to their health. In his words, "some countries could accurately and legitimately be advertised by the following public notice posted on large signs at all border entrances: Warning: this country can be dangerous to your health" (JACKSON, 2000, p. 294).

This representation of danger as illness works for keeping the purity and integrity of the state's 'self'. For Campbell (1992), "it is the extent to which we want to organize the environment-the extent to which we want to purify our 
domain - that determines how likely it is that we represent danger in terms of dirt or disease" (CAMPBELL, 1992, p. 81). However, even in the field of medicine where the binary normal/pathological emerged as a regulative ideal, it has become increasingly inaccurate since the ideal of perfect health (the complete absence of disease) has been proven rare-turning 'disease' into the norm. This illuminates some important aspects in discussions about failed states: (i) the 'other' of the 'failed state' is not the empirical Western state, but a discursive norm of statehood; (ii) the depreciated 'failed state' has to be constantly reproduced in order to give integrity to the 'normal state'. The latter's normality is dependent upon the constant exclusion of its ambiguities through discourse-an asepsis of the 'self'.

These ambiguities and impurities are highlighted, for example, by Rosa Brooks (2005), according to whom 'weak', 'failing' or 'failed' states are the rule rather than the exception. The author reminds us that there is no reason to conceive of the modern state as a particularly successful or benign form of social organization, since its birth and history are everywhere characterised by repression and war-including in Europe. As they expanded, European states superseded other weaker social systems and, having assumed the task of creating unified national cultures, cannibalised their own citizens. The seemingly happy outcome of this story, with the celebration of the UN Charter and the emergence of human rights, did not end the predatory character of the state (BROOKS, 2005). Nonetheless, the discourse on failed states precludes any serious interrogation on the failure of the state as a model, for what is at stake in this discourse is the ability of deviant states to adjust to the image of the 'successful state'-which, through this discourse, has its status of normality reaffirmed.

It is precisely this status of normality that Vivienne Jabri (2010) questions when she writes: "The model state is the European state which, colonialism and the Holocaust notwithstanding, is presented in liberal discourse as the model to be emulated" (JABRI, 2010). The thesis of African deviation is usually postulated without problematizing the Westphalian model-an international order of relatively autonomous states-and without questioning the adequacy of this model for the very European experience. This discourse thus (re)produces the state as a modern regulatory ambition, an ideal of organization to be achieved by all (GROVOGUI, 2002). 
Presenting a conventional view, Michael Ignatieff (2003) understands that, even if 'failed states' undergo singular crises, they all share a common feature: namely, they lose the monopoly over the legitimate means of violence and, therefore, no longer meet Max Weber's classic definition of state. In fact, this Weberian criterion is presented by the conventional literature as the main cleavage factor between 'failed' and 'successful' states. This loss of control over the means of coercion is presented as the main reason for violence and instability in these states, since they are unable to exercise control over their entire territory (HILL, 2005).

Similarly, Robert Rotberg (2002) understands that the geographical extent effectively controlled by the government is a measure of state failure. A functional state can exercise a monopoly over legitimate violence within its territory and, on that basis, can provide security for its population. The corollary of this discourse is the assumption that citizens rely on centralised states for their safety. The centralised state exercising monopoly over the legitimate use of force becomes, therefore, sine qua non for the provision of security, deemed to be the most important political asset. 'Failed states', on the contrary, are defined as those where "public authorities are either unable or unwilling to carry out their end of what Hobbes [...] called the social contract" (GROS, 2003, p. 03).

The above definitions preclude any serious attempt to consider alternative forms of political organization, since they condition us to think that, in the absence of states, all we have left is a Hobbesian state of anarchy. However, as remarked by Jean-German Gros (2003), the contemporary legitimate state is not exactly the same as Weber's since today, in addition to security, the state must provide a wide range of services, from environmental protection to the redistribution of wealthfunctions that are not performed by 'failed states'. For Rotberg (2002), this means that such functions are taken over by warlords and other non-state actors, once "the failed state is no longer able or willing to perform the job of a nation-state in the modern world" (ROTBERG, 2002, p. 87). Failed states would be a 'dark mirror image' of functional states and those characterised by good governance, as they are often represented by their lack of transparency, human rights abuses, insufficient mechanisms of accountability and generalized corruption on the part of the ruling elites (BROOKS, 2005). 


\section{'Failed states' and 'pre-modernity': the temporalisation of difference}

In the failed state discussion, a number of categories and metaphors are used to represent difference as backwardness, creating a temporal distance between Europeans and non-Europeans that reproduces a pattern of the first encounters between Europeans and Amerindians (see BLANEY and INAYATULLAH, 2004). These failed states are often allocated in a condition of a 'Hobbesian state of nature'-an environment that temporally precedes the social contract (see KAPLAN, 1994). According to Jackson (2000), for example, "failed states are juridical shells that shroud an insecure and even dangerous condition domestically, a state of nature" (JACKSON, 2000, p. 296). For R. B. J. Walker (2006), however, Hobbes' narrative on the social contract works to legitimise the state by projecting the problem of men to another time and place: the state of nature. This narrative shows that, for men to become modern, free, mature subjects, they have to organise themselves according to modern structures of authority. In the absence of the latter, they are left to cope with an untamed nature in need of civilisation.

The temporalisation of difference is also produced when authors locate 'failed states' in a state of 'pre-modernity'. In the book The Breaking of Nations, British diplomat Robert Cooper (2003) splits the world into three types of states: pre-modern, modern and postmodern. The 'pre-modern' world would be the one formed by failed and failing states, those unable to meet the Weberian monopoly on the exercise of the legitimate use of force. This situation would have emerged because such states abused their monopoly in the past, thus contributing to their loss of legitimacy. Their contemporary condition became one of fragility, inefficiency and corruption. The void left by the absent state is then occupied by criminal non-state actors, such as terrorist groups and drug traffickers. Such states as Somalia, Afghanistan and Liberia "[belong], as it were, in a different time zone" (COOPER, 2003, p. 17). The three worldviews presented by Cooper are not only temporally separated but their timescale is normatively hierarchised, since the 'pre-modern' stage is defined as 'chaotic' while the 'postmodern' world is defined as a 'zone of peace'. In this sense, Cooper hierarchises different societies by deploying this temporal categorization.

Joshua Forrest (1994) aims, in turn, to comparatively investigate the initial stage of state formation in post-colonial Africa in relation to what was experienced 
by European states, in order to better understand "what politics are about in weak states" (FORREST, 1994, p. 260). To this end, his analysis compresses time to treat states with certain common characteristics under the same analytical frame. He then concludes that weak states are hybrid regimes, where power is shared "by factionalized combinations of national elites grouped according to bureaucratic unit, social class background, region of origin, ethnicity or clientelism, often with the military playing a crucial role in determining the particular leadership structure of these regimes" (FORREST, 1994, p. 260).

Due to the operational fragility of governmental agencies, powerful social forces-like the barons in Europe and the ethnic clientelistic groups in Africa-are able to overcome institutional barriers and affect the decision-making process. In this sense, the struggle for power is unlimited, with components of the state competing among themselves, subject to few legal limits, where the use of force in general-and attempts at a coup d'état particularly-become a common means of political change. This comparative spatial and temporal framework used by Forrest, however, is not innocent or neutral, but hierarchises societies by identifying powerful similarities between post-colonial Africa and Medieval Europe, thus locating them in different developmental stages.

In this sense, even if Forrest's (1994) intention was to 'better understand' the politics of state formation, his comparison has productive force in that it produces African backwardness vis-à-vis the European 'self'. The negative representation of this pre-state stage of political formation as 'unbounded violence' invokes, in turn, Todorov's double movement, according to which difference is first read as inferior and, then, is either assimilated or eradicated ${ }^{1}$.

In this way, both Cooper (2003) and Forrest (1994) inferiorise difference by interpreting it as backwardness. Difference as pre-modern identity is, therefore, delegitimised through a comparison-explicit or implicit-with temporally more advanced identities. According to Blaney and Inayatullah (2004), "asserting one's identity as distinct from modernity-the moment of difference-risks internal fragmentation, limited material "progress" and, what follows, designation as an

1 Todorov's double movement is analyzed by D. Blaney and N. Inayatullah (2004), International Relations and the Problem of Difference. See also: T. Todorov (1999), The Conquest of America: The Question of the Other. 
inferior or backward region (or, in more contemporary terms, the "quasi" or "failed states")"(BLANEY and INAYATULLAH, 2004, p. 114).

Taking into account this temporalisation of difference, the discourse on 'failed states' produces the temporal identity of the so-called 'successful states'. In this sense, 'successful states' are not only able to guarantee security through the monopoly on the legitimate use of force, to provide public goods to their population, to respect democratic principles, to observe human rights, to ensure the efficient functioning of their administrative machine, to promote 'good governance', but they are also states that construct themselves as temporally advanced in relation to their 'failed' and 'backward' counterparts.

\section{The effects of 'state failure'}

The discourse on 'failed states' has political consequences, creating the conditions of possibility for increasingly intrusive interventions. These interventions are undertaken in the name of correcting this situation of failure and are driven by the promise to lead states toward more advanced stages of development.

Gerald Helman and Steven Ratner (1992) categorise the modes of intervention by peacekeeping operations according to the alleged degree of state failure. In order to legitimise the need for UN intervention, the authors divest states of their agency. Their incapacity is constructed through a series of depreciative analogies such as between states and failed families, states and physical and mental illnesses, or even between states and economically deprived people who are placed under the responsibility of a tutor provided by law due to some incapacity to live on their own.

Yet another discursive strategy is to compare the situation of 'failed states' to that of business bankruptcy, when companies are afforded a transitional period guaranteed by bankruptcy codes to reconstitute themselves economically. By discursively producing such states as inept, the authors create the conditions of possibility for the UN to act as trustee, in order to promote the values of human rights and stability contained in its Charter. It becomes clear, then, how this discourse constitutes the 'reality of state failure'. This, in turn, compels the United Nations to act in the face of the inability of 'failed states' to solve their own 
problems. The authors point out that "sovereignty, even as touted by many developing states, is consistent with the idea of conservatorship because the purpose of conservatorship is to enable the state to resume responsibility for itself" (HELMAN and RATNER, 1992, p. 17). They also note that old notions of sovereignty should not prevent such interventions, given the responsibility of the world community for the promotion of human rights that would foster, in the long run, the idea of popular sovereignty in 'failed states'.

Gros' (2003) objective, in turn, is to develop a global taxonomy of 'failed states' since, according to the author, not all states are characterised by the same degree of failure. Thus, instead of merging all 'failed states' into a single category, he places them along a continuum between those that conform to the Weberian formula and are able to provide public services, and those that do not meet any criteria for successful statehood. If the degree of state failure differs, there may be no comprehensive formula to aid them. He argues, then, that there is a substantial difference between a 'failed' and a 'weak' state, since state reconstruction in the former requires much more financial resources and external political and military commitment than in the latter. Also, while 'failed states' demand complete institutional reconstruction, 'weak states' require only that they be strengthened. For Gros (2003), the inability to appreciate the specificities of failed states can thus lead to the adoption of wrong policies by the international community, making external actors more cautious against future intervention. In this sense, for the author, "this way of conceptualizing allows for distinguishing among states in terms of the severity of their failure and most importantly calibrating external intervention according to where states are on the continuum" (GROS, 2003, p. 457).

Along this line, it is important to note that in 2014 the annual Failed States Index changed the terminology from "failed" to "fragile" states, precisely in order to reflect the "continuum of state development" suggesting that states are weak but can improve from their poor situation (PICKERING, 1994). According to J.J. Messner and Hendry (2014):

What the term 'failed State' itself fails to capture is that state failure or fragility really exists along a continuum: it's a continuum within a country, both geographically and also in different aspects of society. The 
continuum also exists over time, and the term 'failed' really suggests a certain degree of finality that really just isn't true. A country can be very weak, and it can recover. That may take some time, but it still doesn't mean that a state will ever be failed for all time (MESSNER and HENDRY, 2014).

So, the introduction of the term 'fragility' reflects an attempt to 'capture a lot more of nuance' and, as such, of providing 'a lot more of an accurate description for the kind of analyses that we are attempting' (MESSNER and HENDRY, 2014).

Nevertheless, this new attempt to rigorously evaluate and classify states goes hand in hand with the perceived need to calibrate the conditions for a successful intervention. The problem with such a taxonomy is that, even if it tries to represent the objective reality by means of an accurate diagnosis of the states, its nature is, as pointed out by Pinar Bilgin and Adam David Morton (2004, p. 173), 'arbitrary' and 'discriminatory'. In this sense, the taxonomy presented by the analytical framework of fragile/failed states produces a hierarchically organised world; this is in relation to a normatively superior model of state success according to which all states are compared, judged and punished.

Similar to Gros (2003), Robert Keohane (2003) normatively ranks deviant states. He argues that the task of building viable liberal democratic institutions is more easily accomplished in 'good neighbours', as in the case of Bosnia, than in 'bad neighbours', like Somalia. Thus, political responses should be different for these regions, guided by a disaggregated concept of sovereignty so that a legitimate authority can be established after intervention. For Keohane (2003), the classical unitary concept of sovereignty, according to which the state has exclusive jurisdiction within a given territory, constitutes an obstacle to the process of postconflict reconstruction and the establishment of a self-sustaining political authority. A fragmented understanding of sovereignty, on the other hand, allows politicians to prescribe institutional arrangements, focused on the performance of certain sovereign functions in states at risk of failure. This, however, does not mean that states should be completely abandoned or that the concept of sovereignty should be discredited. For Keohane (2003), the state remains primarily responsible for protection and collective action in the contemporary world, since nationalism makes the imposition of a foreign government 
unsustainable in the long term, and anarchy continues to be as brutish as stated by Hobbes (KEOHANE, 2003).

Also arguing for a disaggregated concept of sovereignty, Krasner (2004) proposes that 'failed' or 'collapsed' states should use their international legal sovereignty to enter agreements that improve their domestic sovereignty by compromising their Westphalian sovereignty ${ }^{2}$. In this sense, the sovereign capacity to enter voluntary agreements-international legal sovereignty--would be preserved while another central aspect of sovereignty, the principle of political autonomy, would be violated. Reduced state autonomy would result from voluntary agreements of 'shared sovereignty', involving structures of joint authority between the external and the domestic actors in some issue areas. However, such agreements would have to involve "the engagement of external actors in some of the domestic authority structures of the target state for an indefinite period of time" (KRASNER, 2004, p. 108), since explicitly temporary missions reduce the incentives of local actors to support the construction of their states. According to Krasner (2004), "because the contract would have no termination date, local actors could no longer assume that they could simply wait for the foreigners to leave. Some local leaders might still decide that acting as a spoiler might maximize their interests, but others would see cooperation as more likely to enhance their long-term prospects" (KRASNER, 2004, p. 115).

The justifications presented above in favour of intervention and trusteeship by the 'international community' over 'failed states' assume, in general, that such practices are the only way to the regeneration of these states. Once their societies are constructed as incapable of solving their own problems, external forces are left with the role of leading them towards modernity. Thus, external actors are discursively presented as benevolent, restorative forces (HILL, 2005).

In fact, in most of the literature, the United Nations peace operations are perceived as a sign of progress and the 'humanization' of world politics. According to Roland Paris (1997), these interventions are presented as more consensual and

\footnotetext{
2 According to Krasner (2004), international legal sovereignty is associated with the formal juridical independence of states that mutually recognize each other and are able to enter into voluntary agreements. Westphalian sovereignty refers to the respect for selfgovernment and political autonomy. Domestic sovereignty refers to the authority structure of the state inside its territory and over its population.
} 
multilateral than the previous ones, devoid of any exploitative goals, deployed within a determined period of time and even as a 'charitable' action undertaken by the international community on behalf of humanity. Even recognizing the evident differences between the new UN peace operations and colonialism, Paris (2002) argues that the contemporary practice of peace-building can be understood either as a modern version of the old mission civilisatrise, through which the European imperial powers assumed the duty of civilising overseas possessions; or, as a new chapter in the history of the relationship between the developed and the developing world. Although making explicit that the new peace operations are exporting liberal democratic norms from the centre to the periphery of the international system, Paris $(1997,2002)$ does not put the liberal peace model per se into question. Contrary to this view, critical authors, such as Oliver Richmond (2004) and David Chandler (2005), have questioned this model by pointing to its political character, stressing the violence behind the conventional wisdom which presents the liberal peace model as a necessary and unquestionable point of arrival (see MORENO; BRAGA and GOMES, 2012).

\section{Domestic anarchy versus international progress}

By constructing states as 'backward' and incapable of changing their own histories, the discourse on 'failed states' also produces the 'international' as a realm of progress thereby contradicting its traditional characterization as anarchic and marked by recurrent conflicts. To develop this argument, the remainder of this article first analyses how the conventional Anglo-American literature conceives of International Relations; and then, investigates how the discourse on 'failed states' is reversing this logic although it still continues to operate on the same modern demarcation of boundaries between domestic and international.

In his article Why is there no International Theory?, Martin Wight (1966) identified the opposition between political theory, understood as the theory of the good life possible inside the state, and the theory of International Relations, characterised instead by a refutation of the Enlightenment view of progress. According to Wight (1966), International Relations is bound to be a counterpoint to something more authentic and political, namely, life within states. This clear demarcation of borders between life inside and outside of the political community 
was made possible by the principle of state sovereignty, which has circumscribed political and progressive life to territorially demarcated spaces (WALKER, 1993).

In this sense, due to the anarchic nature of the international system and the impossibility of effective political life outside the borders of the state, Brooks (2005) compares international relations to a global failed state. According to her, the 'international community' is similar to an expanded failed state, unable to control violence on the part of its most powerful actors-whether state or nonstate actors, such as terrorist organizations-to control environmental disasters such as global warming, to remedy astronomical economic inequities between and within states, to inhibit the devastating struggle for natural resources, or to deal with global epidemics. Brooks (2005) concludes that, just like Afghanistan and Iraq, which are fractured among competing ethnic and religious groups dominated by warlords, the 'international order' still resembles the Hobbesian state of nature marked by the struggle for survival rather than by a system of coherent governance (BROOKS, 2005).

The claim that states exist in a state of nature is, according to Beate Jahn (1999), the raison d'être of International Relations theory. This claim implies that relations between states are in a pre-social and pre-cultural stage. Namely, that social life (in the way it exists domestically) has not yet spilled over into international relations. This claim is the basis for the distinction between national politics as the domain of authority, and international politics as the domain of struggle and power (JAHN, 1999). Although this discourse on the 'state of nature'-used by both realists and idealists to define international relations-is still alive in the representation of 'failed states', the international domain is being increasingly produced in discourse as a realm of progress (see BLANEY and INAYATULLAH, 2004).

Discourses on 'failed states' subvert the conventional theory of international relations in that, by representing such states as anarchical, they threaten to undermine the opposition between state sovereignty and international anarchy that demarcates an internal domain of order and civility from an external domain of violence, inhumanity and disorder (DOTY, 1996). According to Robert Jackson and Carl Rosberg (1982), the Anglo-American conception of the international system (domestic order versus international discord) could not, in 
the 1980s, address the everyday reality of Africa. This region seemed to experience a reversal of the traditional logic, with the international realm being marked by concord and civility-a structure of rules and conventions governing relations among states-against an internal state of disorder and violence. Therefore, the authors conclude that "the recent national and international history of Black Africa challenges more than it supports some of the major postulations of international relations theory" (JACKSON and ROSBERG, 1982, p. 24).

Before the end of the Cold War, Jackson (2000) introduced the concept of 'quasi-states' to refer to those states that came to enjoy legal sovereignty after World War II, but could not practically perform the duties of a sovereign state efficiently, including the provision of security and well-being to their populations. However, their failure was occluded during the Cold War because they enjoyed external recognition and had their sovereignty respected regardless of their domestic conditions. Thus, the high degree of tolerance by this 'benevolent' international society allowed these unprepared states to have their independence recognised. According to Jackson (2000), "the external guarantee of legal independence is primarily owing to the emergence of a post-colonial international society that is highly tolerant of different degrees of statehood across the world" (JACKSON, 2000, p. 196). After 1945, the international society became informed by a pluralist ethic, that is, an ethic primarily concerned with upholding international order and the sovereignty of independent states. In this context, "political laissez faire was adopted as the universal norm of international society" (JACKSON, 2000, p. 314).

At the same time that the anarchical situation of these 'failed states' became more evident, the end of superpower rivalry and the growth of a normative consensus around liberal democratic values in the international realm contributed to the possibility of thinking in terms of the progress of that international realm. In this sense, the end of the Cold War enabled modernization to be seen as a global process (BLANEY and INAYATULLAH, 2004). This image took many forms, from explanations grounded in liberal theories about the diffusion of the liberal zone of peace to claims about the inexorable process of 'globalisation' bringing about a global civil society. Thus, the end of the Cold War and the 
emergence of 'failed states' allowed for a reversal of the conventional assumption of the dichotomy between domestic order versus international anarchy ${ }^{3}$.

Jackson (2000) underscores this perspective by showing that the existence of 'failed states' reverses the security dilemma since, for them, 'peace usually exists internationally while war exists domestically'. Thus, he concludes that 'failed states turn Hobbes' political theory on its head'. With this reversal, the state of nature no longer takes place in international relations, but in the domestic sphere of 'failed states' (JACKSON, 2000, p. 295).

The discursive construction of 'failed states' as the realm of difference, relativism and violence contributes to the production of the ideas of 'progress' and 'community' in the international arena. Labelling a state 'failed' furthers its exclusion from the 'community of states' that is represented as a coherent community of developed states. Thus, the discourse on 'failed states' promotes the construction of the international as a domain of progress and, consequently, the dismissal of its classic image as a realm of repetition and violence. Demarcating boundaries between these realms remains, however, an integral practice, as the 'failed state' works as the 'other' of the 'international'.

\section{It is the 'other's' fault}

As 'others', the so-called 'failed states' need to be continuously contained to prevent domestic disorder/anarchy from spilling over and spoiling the progress of the 'international' - which, if it happened, could give validity to Brooks'(2005) idea of the 'international' as a major failed state (BROOKS, 2005). Thus, the distinction between domestic and international politics, established by the discipline of International Relations, continues to inform the literature on state failure, even if the alleged threat has moved from the international to the domestic realm of 'failed states' (HILL, 2005).

A common discursive strategy, used to draw a clear line discriminating 'failed states' from the international realm, consists of allocating the blame for their failure exclusively on domestic factors. The blame is, thus, on the 'failed

\footnotetext{
${ }^{3}$ Jackson and Rosberg (1982) had already called attention to this reversal during the Cold War, but it is argued here that it was only with its demise, with the introduction of the discourse on 'failed states' and the greater discursive emphasis on international progress, that this inversion became more evident.
} 
states' themselves, as if their current problems did not refer back to global processes that have historically impinged on them. In this sense, the impact of colonial powers as well as that of superpower rivalry over these 'underdeveloped' states has been increasingly neglected in the conventional literature, while the domestic dimensions of state failure are continuously emphasised.

According to Charbonneau (2009), African conflicts are broadly described as ensuing from pre-modern cultural norms and identities; in short, they are seen as a sign of the inability of African states to live up to the principle of sovereignty (CHARBONNEAU, 2009). In fact, the conventional literature usually justifies the traditional practices of these states on the basis of their pre-colonial past. Hence, their economic, social and political problems are primarily associated with internal factors. Rotberg (2002), for example, draws attention to the fact that state failure depends on certain decisions made by the ruling groups: "state failure is manmade, not merely accidental nor-fundamentally-caused geographically, environmentally, or externally" (ROTBERG, 2002, p. 93). Jackson (2000), in turn, underlines the internal dimension of state failure by affirming that "they have selfdestructed by armed anarchy from within. Their adverse condition is self-inflicted" (JACKSON, 2000, p. 295).

To the extent that the failure of these states is linked to endogenous factors (such as incompetence and endemic corruption), they are seen as incapable of self-government; this creates the conditions for a 'benevolent' intervention by the restorative forces of the 'international community'. In this sense, reconstruction efforts assume that foreign intervention is better than no intervention (COYNE, 2006). External actors, such as foreign governments and international organizations, are represented as the only forces capable of saving 'failed states' from themselves (HILL, 2005). The prescription for salvation inexorably comes in the form of the so-called 'liberal consensus' whose key ingredients are institution-building, the establishment of the rule of law and democratic governance (RICHMOND, 2004).

By shifting the focus on the problem of disorder to the domestic domain, the international domain becomes the only place where a solution to the problem of 'failed states' can be found (BICKERTON, 2007, p. 102). 
In this sense, the discourse underlining the domestic roots of state failure is fundamentally silent about the global processes that contributed to such 'failure'. Such historical amnesia, undertaken by the mainstream literature, unjustly places blame on the victims by associating African problems with internal factors, making it difficult to imagine that Africans themselves may be able to solve their own problems (CRAWFORD, 1996).

Pierre Englebert (1997) problematises this literature by drawing attention to the fact that the contemporary state, in sub-Saharan Africa, is not African since it descends from random colonial units. Not only were these states transformed and adapted, which is a generally accepted statement, their origin is exogenous because it is European. According to the author, it is precisely this exogenous character of the state that explains the numerous examples of state failure in Africa, since states have no roots there. This creates a deficit of legitimacy and a number of problems related to patterns of depredation, patrimonialism and administrative decay.

Along the same lines, Kaplan (2009) argues that one of the reasons why current fragile states struggle to build effective government systems is that their externally imposed institutions are weak and disconnected from their societies, much the same as the colonial administrations were. "The pattern established when the colonial powers arrived and built their administrations on top of, and disconnected from, local societies was essentially continued in most of today's fragile states at independence: governments are largely divorced from and autonomous of the societies that they are supposed to serve" (KAPLAN, 2009).

Even when conventional authors acknowledge the adverse impact of global factors, they do not recognise them as the main causes for the failure of states but insist on the aggravating impact of internal causes, such as corruption, maladministration and lack of economic planning (IGNATIEFF, 2003). The problem with such an approach, however, is that it treats international and domestic causes as isolated rather than indissoluble variables. Moreover, by characterizing 'failed states' as incompetent and irresponsible, this discourse precludes any possibility for thinking they may develop alternative governance mechanisms that are more effective than the ones imposed by international operations. 


\section{Conclusion}

This article explored how the literature on 'failed states' (re)produces the modern state as a regulatory ideal, obscuring its contingent character and its violent foundation. The modern state is normalised through a series of discursive practices that construct the 'failed state' as deviant. The dominant representation of 'failed states' as 'abnormal' or 'backward' limits our political imagination, preventing the development of more comprehensive research on alternative forms of political organization that do not refer to the modern state.

The article draws attention to one of the ways in which this deviancy is being represented, namely, as a backward version of the European 'self'. In this version, difference is accommodated in developmental stages along a linear Eurocentric history. This strategy of temporalisation of difference, largely neglected by the discipline of International Relations due to its focus on the spatial dimension of the international system as an anarchic realm, continues to serve as a powerful instrument for hierarchising peoples and cultures. This hierarchy, in turn, creates the conditions for the possibility of certain interventionist practices aimed at assimilating difference under modern structures of authority.

The agents of such interventionist practices are represented in the form of a 'progressive' and 'benevolent' 'international community'. This article analysed how a series of discursive strategies contribute to this representation, problematising their attempt to associate state failure with an exclusively domestic process-an attempt that occludes the impact of the multiple historical encounters with global actors and processes. These discursive strategies produce a welldemarcated boundary between the domestic level of 'anarchy' and the international realm of 'order' and 'progress', preventing disruption of the latter by the former-something that would happen if these external/global processes were historically identified with the causes of anarchy in these regions. In any case, Somalia, Rwanda, Liberia, Haiti and many other states represented as 'backward' and 'violent' remain fundamental to the existence of a 'progressive', 'liberal' and 'peaceful' West.

Accordingly, this article sought to show that the traditional image of an anarchical system versus an ordered and progressive state is turned on its head when viewed from the perspective of 'failed states'. In the latter, domestic anarchy 
is contrary to a modernizing international realm. By labelling the 'other' as 'traditional', 'failed', and 'backward' in contradistinction to a 'modern', 'successful' and 'progressive' international, the dominant discourse conditions us to conceive of these realms as homogeneous in themselves and radically different from each other, rather than as liminal areas with numerous ambiguities and overlaps.

Revised by Viamundi Submitted in October 2014 Accepted in July 2015

\section{References}

BICKERTON, Christopher J. (2007), State-building. Exporting state failure. In: BICKERTON, Chirstopher; CUNLIFFE; Philip and GOUREVITCH, Alexander (Ed.). Politics without Sovereignty: a critique of Contemporary International Relations. London: University College London Press. pp. 93-111.

BILGIN, Pinar and MORTON, Adam D. (2004), From "Rogue" to Failed States: the fallacy of short-termism. Politics. Vol. 24, № 03.

BLANEY, David and INAYATULLAH, Naeem (2004), International Relations and the Problem of Difference. New York: Routledge. 272p.

BROOKS, Rosa E. (2005), Failed States, or the State as Failure? The University of Chicago: Law Review. Vol. 72, № 04, pp. 1159-1196.

BROWN, Chris (1994), Turtles All the Way Down: Anti-Foundationalism, Critical Theory and International Relations. Millennium: Journal of International Studies. Vol. 23, № 02, pp. 213-236.

CAMPBELL, David (1992), Writing Security. United States Foreign Policy and the Politics of Identity. Minneapolis: University of Minnesota Press. 427p.

CHANDLER, David (2005), Introduction: Peace without Politics. International Peacekeeping. Vol. 12, № 03, pp. 307-21.

CHARBONNEAU, Bruno (2009), The Colonial Legacy of Peace (building): France, Europe, Africa. Paper presented at the ISA Annual Convention, New York.

COOPER, Robert (2003), The Breaking of Nations: Order and Chaos in the twenty first Century. London: Atlantic Books. 156p.

COYNE, Christopher (2006), Reconstructing Weak and Failed States: Foreign Intervention and the Nirvana Fallacy. Foreign Policy Analysis. Vol. 02, № 04, pp. 343-360.

CRAWFORD, Neta C. (1996), Imag(in)ing Africa. The Harvard International Journal of Press/Politics. Vol. 01, № 02, pp. 30-44. 
DOTY, Roxanne L. (1993), Foreign Policy as Social Construction: A Post-Positivist Analysis of U.S. Counterinsurgency Policy in the Philippines. International Studies Quarterly. Vol. 37, № 03, pp. 297-320.

DOTY, Roxanne L. (1996), Imperial encounters: the politics of representation in north-south relations. Minneapolis: University of Minnesota Press. 224p.

ENGLEBERT, Pierre (1997), The Contemporary African State: neither African nor state'. Third World Quarterly. Vol. 18, № 04, pp. 767-775.

FOUCAULT, Michel (2004), Soberania e Disciplina. In: Microfísica do Poder. São Paulo: Edições Graal. pp. 100-106.

FORREST, Joshua (1994), An Asynchronic Comparison: Weak States in PostColonial Africa and Medieval Europe. In: DOGAN, M. and KAZANCIGIL, A. (eds.). Comparing Nations: Concepts, strategies, substance. Oxford: Blackwell. pp. 260-296.

GROS, Jean-Germain (2003), Toward a Taxonomy of Failed States in the New World Order: Decaying Somalia, Liberia Rwanda and Haiti. Third World Quarterly. Vol. 17, № 03, pp. 455-471.

GROVOGUI, Siba (2002), Regimes of Sovereignty: International Morality and the African Condition. European Journal of International Relations. Vol. 08, № 03, pp. 315-338.

HAGMANN, Tobias (2005), From State Collapse to Duty-Free Shop: Somalia's Path to Modernity. African Affairs. Vol. 104, Issue 416, pp .525-535.

HANSEN, Lene (2006), Security as Practice. Discourse Analysis and the Bosnian War. New York: Routledge. 288p.

HELMAN, Gerald B. and RATNER, Steven B. (1992), Saving Failed States. Foreign Policy. № 89, pp. 03-20.

HILL, Jonathan (2005), Beyond the Other? A postcolonial critique of the failed state thesis. African Identities. Vol. 03, Issue 02, pp.139-154.

IGNATIEFF, Michael (2003), State Failure and Nation-Building. In: HOLZGREFE, J. L. and KEOHANE, Robert (eds.). Humanitarian Intervention: Ethical, legal and political dilemmas. Cambridge: Cambridge University Press. pp. 299-321.

JABRI, Vivienne (2010), War, Government, politics: a critical response to the hegemony of the liberal peace. In: RICHMOND, Oliver (ed.). Palgrave advances in Peacebuilding. Nova York: Palgrave Macmillan, pp. 41-57.

JACKSON, Robert (2000), The Global Covenant: Human Conduct in a World of States. Oxford: Oxford University Press. 464p. 
JACKSON, Robert and ROSBERG, Carl (1982), Why Africa's Weak States Persist: The empirical and juridical in statehood. World Politics. Vol. 35, № 01, pp. 0124.

JAHN, Beate (1999), IR and the state of nature: the cultural origins of a ruling ideology. Review of International Studies. Vol. 25, № 03, pp. 411-434.

KAPLAN, Robert (1994), The Coming Anarchy. The Atlantic Monthly. Vol. 273, № 02, pp. 44-76.

KAPLAN, Seth (2009), Rethinking state building: Fixing fragile states. The Broker. 07 October, http://www.thebrokeronline.eu/Articles/Rethinking-statebuilding. [Accessed in 9 November 2010]

KEOHANE, Robert (2003), Political Authority after intervention: gradations in sovereignty. In: HOLZGREFE, J. L. and KEOHANE, Robert (eds.). Humanitarian Intervention: Ethical, legal and political dilemmas. Cambridge: Cambridge University Press. pp. 275-298.

KRASNER, Stephen (2004), Sharing Sovereignty; New Institutions for Collapsed and Failing States. International Security. Vol. 29, № 02, pp. 85-120.

LYONS, Terrence and SAMATAR, Ahmed (1995), Somalia: State Collapse, Multilateral Intervention and Strategies for Political Reconstruction. Washington: The Brooking Institution. 112p.

MALMVIG, Helle (2006), State Sovereignty and Intervention. A discourse analysis of interventionary and non-interventionary practices in Kosovo and Algeria. New York: Routledge. 196p.

MESSNER, J.J. and HENDRY, Krista (2014), The failed states index becomes the fragile states index, http://library.fundforpeace.org/blog-20140528fsinamechange [Accessed in 10 September 2014].

MILLEKEN, Jennifer (1999), The Study of Discourse in International Relations: A Critique of Research and Methods. European Journal of International Relations. Vol. 05, № 02, pp. 225-254.

MORENO, Marta; BRAGA, Carlos and GOMES, Maíra (2012), Trapped between many worlds: a post- colonial perspective on the UN Mission in Haiti (MINUSTAH). International Peacekeeping. Vol. 19, № 03, pp. 377-392.

PARIS, Roland (1997), Peacebuilding and the Limits of Liberal Internationalism. International Security. Vol. 22, № 02, pp. 136-175.

PARIS, Roland (2002), International Peacebuilding and the Mission Civilisatrice. Review of International Studies. Vol. 28, № 04, pp. 637-656. 
PICKERING, Heath. (1994), Terminology twist: from failed to fragile states, http://www.aspistrategist.org.au/terminology-twist-from-failed-states-tofragile-states/ [Accessed in 10 September 2014].

RICHMOND, Oliver (2004), The Globalization of Responses to Conflict and the Peacebuilding Consensus. Cooperation and Conflict. Journal of Nordic International Studies Association. Vol.39, № 02, pp.129-50.

ROTBERG, Robert I. (2002), The New Nature of Nation-State Failure. The Washington Quarterly. Vol. 25, Issue 03, pp. 85-96.

SCHMITT, Carl (1985), Political Theology: four chapter on the concept of sovereignty. Chicago and London: The University of Chicago Press. 116p.

SHAPIRO, Michael (1989), Textualizing Global Politics. In: SHAPIRO, Michael and DER DERIAN, James (eds.) International/Intertextual Relations. Postmodern Readings of World Politics. Toronto: Lexington Books. pp. 11-22.

TODOROV, Tzevetan (1999), The Conquest of America: The Question of the Other, Norman: University of Oklahoma Press. 61p.

WALKER, Rob B. J. (2006), The Double Outside of the Modern International. Ephemera, Theory \& Politics in Organization. Vol. 06, № 01, pp. 56-69.

WALKER, Rob B. J. (1993), Inside/Outside: International Relations as Political Theory. Cambridge: Cambridge University Press. 233p.

WIGHT, Martin (1966), Why Is There No International Theory? In: BUTTERFIELD, Herbert and WIGHT, Martin (eds.). Diplomatic Investigations. London: George Allen and Unwin, pp. 17-34. 